Original Article

\title{
Wild birds trade in Dera Ismael Khan and Bannu divisions of Khyber PakhtunKhwa (KPK) Province, Pakistan
}

\author{
Comércio de aves selvagens nas divisões Dera Ismail Khan e Bannu da província de \\ Khyber Pakhtunkhwa (KPK), Paquistão
}

\author{
A. Hussain ${ }^{2 *}(1)$ and A. A. Khan ${ }^{\mathrm{a}}($ () \\ aBahauddin Zakariya University, Institute of Pure \& Applied Biology, Multan, Pakistan
}

\begin{abstract}
Wildlife trade is a profitable economic activity. Birds are among the most heavily traded animals worldwide, with numerous species threatened by pet trade. The present case study was stretched for period of one year to find out the status of wild birds' trade in Bannu and Dera Ismael Khan Divisions. The study was aimed to find out the types of species, commercial prices of bird, trade routes, overall income generated from birds' trade and the status of dealers whether licensed or not. Bimonthly visits were conducted to interview 52 bird dealers/pet shops owners/venders (23 in Dera Ismael Khan and 29 in Bannu). A sum of 16 conceivable sites were visited during the study period. Out of these, 8 sites were located in Dera Ismael Khan and 8 sites in Bannu Division. The highest priced species was Demoiselle crane (Grus virgo) and the lowest priced species was house sparrow (Passer domesticus). Total number of species traded in both regions were 8 and 14 while the income generated by bird trade was amounting to PkR $1,322,200$ and 7,128,950 in Dera Ismael Khan and Bannu respectively. Majority of the birds were trapped locally with the exception of few from adjacent areas. Commercial activity led by illegal bird traders was found $75 \%$ and $100 \%$ species in Dera Ismael Khan and Bannu respectively. There was no significant difference between prices of birds, number of species sold and income generated by bird trade in two divisions.
\end{abstract}

Keywords: Birds'trade, Dera Ismael Khan, Bannu, Khyber Pakhtunkhwa, Pakistan.

\section{Resumo}

O comércio de animais selvagens é uma atividade econômica lucrativa. Os pássaros estão entre os animais mais comercializados em todo o mundo, com inúmeras espécies ameaçadas pelo comércio de animais de estimação. $\mathrm{O}$ presente estudo de caso foi estendido por um período de um ano para descobrir a situação do comércio de aves selvagens nas Divisões Bannu e Dera Ismael Khan. O estudo teve como objetivo descobrir os tipos de espécies, os preços comerciais das aves, as rotas comerciais, a receita geral gerada pelo comércio de aves e o status dos negociantes, licenciados ou não. Visitas bimestrais foram realizadas para entrevistar 52 comerciantes de pássaros / proprietários / vendedores de pet shops (23 em Dera Ismael Khan e 29 em Bannu). Uma soma de 16 locais concebíveis foram visitados durante o período de estudo. Destes, 8 sites estavam localizados em Dera Ismael Khan e 8 sites na Divisão Bannu. A espécie com preço mais alto foi o guindaste Demoiselle (Grus virgo) e a espécie com preço mais baixo foi o pardal (Passer domesticus). O número total de espécies comercializadas em ambas as regiões foi de 8 e 14, enquanto a receita gerada pelo comércio de aves foi de PkR 1.322.200 e 7.128.950 em Dera Ismael Khan e Bannu, respectivamente. A maioria das aves foi capturada localmente, com exceção de algumas das áreas adjacentes. A atividade comercial liderada por comerciantes ilegais de aves foi encontrada com $75 \%$ e $100 \%$ de espécies em Dera Ismael Khan e Bannu, respectivamente. Não houve diferença significativa entre os preços das aves, o número de espécies vendidas e a receita gerada pelo comércio de aves nas duas divisões.

Palavras-chave: comércio de pássaros, Dera Ismail Khan, Bannu, Khyber Pakhtunkhawa, Pakistan

\section{Introduction}

Relationship between men and animals dates back thousands of years. The various interactions maintained among animals and man is the theme of Ethnozoology. Within its perspective, Ethnozoology can be regarded as a discipline that scrutinizes the economic, historical, anthropological, sociological and environmental facets of the relationships between humans and animals (Alves, 2012).
Wildlife has changed its dimension in the recent years from subsistence to commercial trade. Southeast Asia is the epicenter of wildlife trade. Indonesia is a country with high levels of illegal and unsustainable wildlife trade (Nijman, 2010). Exploitation of birds and their captivity by human is posing a great risk for extinction to domestic and wild birds in Brazil (Shepherd, 2006). Birds including parrots of Caatinga biome attained cultural, economic and

*e-mail: ashrafkharick@gmail.com

Received: January 24, 2021 - Accepted: May 3, 2021 
social value for Brazilian community due to their usage for pleasure, ornamentation and companionship. Moreover, it is found that the illegal trade of songbirds is as a main cause for bird's population decline (Oliveira et al., 2018 , 2020). Indonesia now has more species of birds declared as threatened with extinction than any other country in Asia, and is second only to Brazil (164) throughout the world, with 131 threatened bird species (IUCN, 2014).

Birds have been used by human for many purposes. The fashion of wearing bird wings in ladies' caps started in the court of Louis XVI of France when Marie Antoinette used them in a hood with plume tufts. For this purpose herons and other swimming birds along the east coast and in the Everglades were caught in enormous numbers (Doughty, 1975).

Pakistan's fauna and flora is also threatened due to commercial exploitation. All the provincial governments in Pakistan paid their special attention to safeguard their fauna and flora by enacting various laws. Khyber Pakhtunkhwa government gives a high priority to the preservation of quality of widely varied flora and fauna. Therefore, in 1975, Kyber PakhtunKhwa Wildlife (Protection, Preservation, Conservation and Management) Act was promulgated to protect wildlife and was revised in 2015. The KPK province runs some $700 \mathrm{~km}$ from south to north. In south climate is hot in Dera Ismael Khan and Bannu to chilly in Chitral. The province is enriched with 100 types of mammals, more than 456 types of birds, 46 types of reptiles and more than 4000 types of plants (Shah, 2011).

Ever since, mid-1960s Pakistan allowed falconers from Gulf countries to hunt the Houbara bustard (Chlamydotis undulata) under special licenses. Therefore, until the mid $80 \mathrm{~s}$, the hunting parties were allowed to kill between 3,000 and 7,000 birds per annum (Mian, 1986). In Western Balochistan province during 1982-1983 some 5,000-6,000 birds were killed (Nadeem et al., 2005). Evidently, the overall population in Sindh and Punjab faced 30\% decline during 1960 to 1971 (Mirza, 1985). This worrying decline of the Houbara bustard population sparked in the initiation of conservation efforts by Arab falconers. The Arabs initiative by investing resources for sustainable conservation to safeguard Houbara in critical areas helped in population stability. The situation in Pakistan is worse with respect to wildlife. Rapid urbanization and deforestation are playing havoc to wildlife. The recent changing pattern of climate is eye opener for the Government. Forestation and conservation strategies are needed to save the limited gene pool. The billion tree Tsunami project was started by the Government to change prevailing climatic pattern of country.

Keeping in view the sustainable conservation of species, it is pertinent to monitor the status of trade/ commercial exploitation and the uses of wild birds in Pakistan. The main objectives of the study were to ascertain the extent of various wild bird species' traded in these divisions of KPK by measuring the legal and illegal financial impact of this trade. This is the first study on general bird trade ever conducted in Khyber Pakhtunkhwa.

\section{Materials and Methods}

The present study was conducted in two Divisions of Khyber Pakhtunkhwa Province, Dera Ismael Khan Division (Dera Ismael Khan and Tank district), Bannu Division (Bannu and Lakki Marwat district) for a period of two years. In a reconnaissance, pet shop owners and bird venders were interviewed to find out the extent of bird trade in two regions. Data about the bird trade was collected by using two methods: primary method and secondary method. In primary method market observations were carried out to enlist total number of pet shop owners in two divisions and total number of species traded in two divisions. The owners of pet shops and venders were interviewed to collect the volume of trade and the prices of birds in two divisions. In secondary method, data about licensing record of dealing birds was collected from wildlife Department. In order to avoid any conflict and bias, information was collected in the garb of being dealer (Albuquerque et al., 2014).

The inventory of number of dealers noted from the market was compared with provincial Wildlife Department record so as to find how many of them were licensed or having CITE permit. The actual number of birds being sold in shops was counted so as to judge trapping density and species of birds traded on the ground as secondary data. Bird species involved in trade were identified with field guide to Birds of Pakistan (Mirza and Wasiq, 2012). Informal discussions were done with wildlife, forest and national park managers to get clue about the bird species being traded and their trade routes.

The total number of commercially trading sites visited in Dera Ismael Khan was 8 and birds dealers interviewed were 23 . Whereas, the numbers of commercially trading sites visited in Bannu Divisions were 8 and birds dealers interviewed were 29 as shown in Table 1. Photographs were taken wherever possible as evidence. Samsung galaxy J1 mobile camera was used for this purpose.

\subsection{Mathematical and statistical design:}

The Jackknife 1 technique was used to estimate the number of bird species traded in these divisions of Khyber Pakhtunkhwa as our data bank is composed of information gleaned from bibliographic references and this method uses incidence to generate its estimates. This technique has been successfully utilized by many authors to estimate bird species richness as well as the richness of known birds from interviewer data (Licariao et al., 2013; Roldán-Clarà et al., 2017). All the data was put in SPSS version 21 for analysis. ANOVA was applied and P-value was calculated to compare prices of birds, number of birds traded and income generated for different species in two divisions.

\subsection{Study area}

Bannu is the smallest division of Khyber Pakhtunkhwa. It lies between $32^{\circ} 16^{\prime} \mathrm{N}$ and $33^{\circ} 5^{\prime} \mathrm{N}$ and between $70^{\circ} 23^{\prime} \mathrm{E}$ and $71^{\circ} 16^{\prime} \mathrm{E}$, with an area of 1,670 square miles. Two rivers pass through this division starting from the hills of Waziristan, the Kurram River and Gambila. On its north is the Teri, the tehsil of Kohat District, on its east is Khattak Niazi range 
Table 1. Comparison of No. of wild bird shops / venders in Bannu and Dera Ismael Khan.

\begin{tabular}{|c|c|c|c|c|c|c|c|}
\hline \multicolumn{4}{|c|}{ Dera Ismael Khan Division } & \multicolumn{4}{|c|}{ Bannu Division } \\
\hline Cities & $\begin{array}{l}\text { No. of wild } \\
\text { birds shop }\end{array}$ & Birds venders & Sum & Cities & $\begin{array}{l}\text { No. of wild } \\
\text { birds shop }\end{array}$ & Birds venders & Sum \\
\hline D.I.Khan & 7 & 0 & 7 & Bannu & 6 & 0 & 6 \\
\hline Tank & 3 & 3 & 6 & Lucky Marwat & 1 & 3 & 4 \\
\hline Paharpur & 0 & 1 & 1 & Azeem Killa & 0 & 5 & 5 \\
\hline Prova & 1 & 0 & 1 & Tajori & 0 & 3 & 3 \\
\hline Ramak & 1 & 0 & 1 & Domail & 1 & 0 & 1 \\
\hline Drabin & 1 & 4 & 5 & Saray Naurang & 0 & 5 & 5 \\
\hline DarraPizzu & 0 & 1 & 1 & Ghazni Khail & 0 & 3 & 3 \\
\hline Kulachi & 2 & 0 & 2 & Mungiwala & 2 & 0 & 2 \\
\hline \multicolumn{4}{|c|}{ Grand total $=23$} & \multicolumn{4}{|c|}{ Grand total $=29$} \\
\hline
\end{tabular}

and, on south are Marwat and Bhittanni ranges and on the west and north-west lie Waziristan and independent territory inhabited by the Bhittanni tribe (Bannu District). The area is dry scrub forest. It has two districts (Bannu and Lakki Marwat) as shown in Figure 1.

Dera Ismail Khan Division lies between $31^{\circ} 33^{\prime} 0^{\prime \prime} \mathrm{N}$, $70^{\circ} 10^{\prime} 0$ " E. It includes Dera Ismail Khan District and Tank District. Dera Ismael Khan is separated from Lakki Marwat district by a clay and sandstone hills that stretch east from the Sulaiman Mountains to the Indus River known as the Sheikh Buddin Hills. The highest peak in the range is the limestone Sheik Baddin Mountain with protected area of Sheikh Buddin National Park (Tolbort, 1871). Its tehsils are Dera Ismail Khan, Kulachi, Darabin, Proa and Paharpur.

\section{Results}

\subsection{Market size and major bird species traded}

In Dera Ismael Khan Division, we found 8 bird species with total number of 13285 birds being traded in different sites. The frequency of birds'species being traded were common quail Coturnix coturnix( (90.3\%), Rose ringed parakeet Psittacula krameri (5.5\%), Calendra lark Melanocorypha bimaculata (1.5\%), Eurassian collared dove Streptopelia decaocto (1.1\%), Black partridge Francolinus francolinus (0.7\%), Common starling Sturnus vulgaris (0.3\%), Chukar partridge Alectorus chukar (0.1\%) and Alexanderine parakeet Psittacula eupatra (0.07\%) (Table 2).

In Bannu division, 14 birds species were found in the market with sum of 8087 birds. The species of bird traded according to their volume were, Common quail (62.6\%), Black partridge (10.4\%), Chukar partridge (8.5\%), Calendra lark (5.4\%), Common myna Acridotheres tristis (4.0\%), Rose ringed parakeet (2.5\%), Red vented bulbul Pycnonotus cafer (1.9\%), Common crane Grus grus (1.4\%), House sparrow Passer domesticus (1.2\%), Demoiselle crane Grus virgo (0.6\%) Eurassian collared dove Streptopelia decaocto (0.6\%), Bank myna Acridotheres ginginianus ( $0.3 \%$ ), white eared bulbul
Pycnonotus leocotis (0.1\%) and Alexanderine parakeet Psittacula eupatra (0.02\%) (Table 2).

\subsection{Comparative number of bird trade in two divisions}

The total numbers of wild birds traded in two divisions were 21,372. Percentage of birds traded in Dera Ismail khan was $62 \%$ followed by $38 \%$ in Bannu. During the study, total number of birds sold in Dera Ismael Khan Division were 13285 , while the maximum number of bird sold in Bannu Division were 8087 . The preferred traded bird species in Dera Ismael Khan was Common quail ( $\mathrm{n}=12000)$ and least traded species was Alexanderine parakeet $(n=10)$. Whereas, in Bannu, again preferred traded species was of Common quail $(n=5070)$ while minimum traded species was Alexanderine parakeet $(n=2)$ Table 2. Statistically, the number of birds sold in two divisions were non-significant (P-value=0.34).

\subsection{The prices of birds and income generated in two divisions}

The total income generated in two divisions was PkR 8,451,150 rupees. The income generated by the bird dealers in Dera Ismael Khan was PkR 1,322,200 (15\%), while in Bannu it was PkR 7,128,950 (85\%). Maximum income yielding species in Dera Ismael Khan was Black partridge (PkR 629000) and minimum income yielding species was Common starling (PkR 13,500), while in Bannu, maximum income yielding species was Black partridge (PkR 2,964,500.). The high priced species was Demoiselle crane @ PkR 12000 whereas, the lowest priced species was House sparrow @ PkR 50 (Table 2). The market's price rate of same species in both divisions were nonsignificant ( $\mathrm{P}$-value=0.85). The income generated with respect to variety of species in both divisions was also non-significant (P-value=0.31).

\subsection{Bird trade routes}

Common quail, Black partridge, Chukar partridge, Calendra lark and Common starling are locally trapped species in these divisions. While a small number of Black partridges 


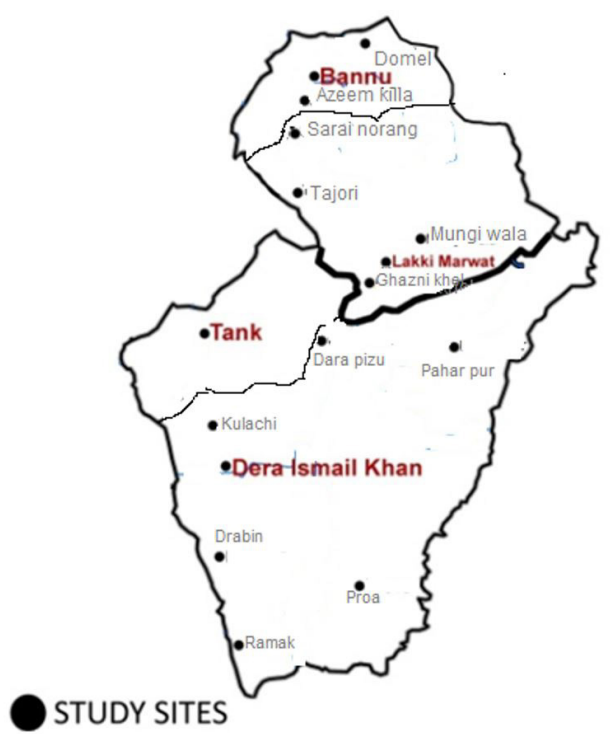

Figure 1. Map showing various study sites in Bannu and Dera Ismail Khan Divisions. and Chukar partridge are brought from adjacent areas like Kohat, Federally Administrated Tribal Area FATA (now part of Khyber Pakhtunkhwa) and Zhob while Alexanderine parakeet is trapped in northern areas of Khyber Pakhtunkhwa and Azad Kashmir. However, most of the Rose ringed parakeet reach in the areas from plains of Punjab province. Calendra lark trapped in Afghanistan is smuggled into these areas for trade. Eurasian collard dove, white eared bulbul, Red vented bulbul, Common myna, Bank myna, Common crane, Demoiselle crane and House sparrow are locally trapped species.

\subsection{Status of bird trade: legal or illegal}

In Dera Ismael Khan, the trade of Rose ring parakeet and Common quail is partially legal while all other 6 species of birds are traded illegally. 70\% quail dealers were licensed while 30\% unlicensed in Dera Ismael Khan Division. Whereas, in Bannu, none of 14 species is traded legally. It means that all the dealers of quails and parrots were trading without license. There is $100 \%$ illegal trade in Bannu division (Table 3). Rest of the above mentioned species were being commercially exploited without legal cover in both divisions

Table 2. Comparison of two divisions with reference to bird species, their unit price, volume of trade and income generated during study period.

\begin{tabular}{|c|c|c|c|c|c|c|c|c|c|}
\hline \multicolumn{6}{|c|}{ Dera Ismael Khan Division } & \multicolumn{4}{|c|}{ Bannu Division } \\
\hline Common name & Scientific name & $\begin{array}{c}\text { Price/ } \\
\text { bird } \\
\text { In PKR }\end{array}$ & $\begin{array}{l}\text { Estimated } \\
\text { No. sold }\end{array}$ & $\%$ & $\begin{array}{l}\text { Income } \\
\text { generated }\end{array}$ & $\begin{array}{c}\text { Price/ } \\
\text { bird } \\
\text { In PKR }\end{array}$ & $\begin{array}{l}\text { Estimated } \\
\text { No. sold }\end{array}$ & $\%$ & $\begin{array}{l}\text { Income } \\
\text { generated } \\
\text { In PKR }\end{array}$ \\
\hline Common Quail & Coturnix coturnix & 55 & 12000 & 90.3 & 66000 & 65 & 5070 & 62.6 & 329550 \\
\hline Black Partridge & $\begin{array}{l}\text { Francolinus } \\
\text { francolinus }\end{array}$ & 3300 & 105 & 0.7 & 346000 & 3500 & 847 & 10.4 & 2964500 \\
\hline Chukar Partridge & Alectorus chukar & 2700 & 25 & 0.1 & 67500 & 2500 & 690 & 8.5 & 1725000 \\
\hline Calendra Lark & $\begin{array}{l}\text { Melanocorypha } \\
\text { bimaculata }\end{array}$ & 370 & 210 & 1.5 & 77700 & 350 & 440 & 5.4 & 154000 \\
\hline Common Starling & Sturnus vulgaris & 300 & 45 & 0.3 & 13500 & 0 & 0 & 0 & 0 \\
\hline $\begin{array}{l}\text { Rose ring } \\
\text { Parakeet }\end{array}$ & Psittacula krameri & 850 & 740 & 5.5 & 629000 & 1400 & 205 & 2.5 & 287000 \\
\hline $\begin{array}{l}\text { Alexandrine } \\
\text { Parakeet }\end{array}$ & Psittacula eupatra & 8500 & 10 & 0.07 & 85000 & 6000 & 2 & 0.02 & 12000 \\
\hline $\begin{array}{c}\text { Eurasian Collared } \\
\text { Dove }\end{array}$ & Streptopelia decaocto & 250 & 150 & 1.1 & 37500 & 250 & 50 & 0.6 & 12500 \\
\hline $\begin{array}{l}\text { White eared } \\
\text { Bulbul }\end{array}$ & Pycnonotus leocotis & & & & & 150 & 10 & 0.1 & 1500 \\
\hline $\begin{array}{l}\text { Red vented } \\
\text { Bulbul }\end{array}$ & Pycnonotus cafer & & & & & 100 & 159 & 1.9 & 15900 \\
\hline Common Myna & Acridotheres tristis & & & & & 300 & 324 & 4.0 & 97000 \\
\hline Bank Myna & $\begin{array}{l}\text { Acridotheres } \\
\text { ginginianus }\end{array}$ & & & & & 200 & 25 & 0.3 & 5000 \\
\hline Common crane & Grus grus & & & & & 8000 & 115 & 1.4 & 920000 \\
\hline Demoiselle Crane & Grus virgo & & & & & 12000 & 50 & 0.6 & 600000 \\
\hline \multirow[t]{2}{*}{ House Sparrow } & Passer domesticus & & & & & 50 & 100 & 1.2 & 5000 \\
\hline & & & $\begin{array}{l}\text { Total }= \\
13285\end{array}$ & & $\begin{array}{c}\text { Total= } \\
1,322,200 \\
\text { PKR }\end{array}$ & 0 & 8087 & & $\begin{array}{c}\text { Total } \\
\text { income= } \\
7,128,950 \\
\text { PKR }\end{array}$ \\
\hline
\end{tabular}


Table 3. Comparison of Licensed and unlicensed dealers of Parrot and Quail in Dera Ismael Khan and Bannu Divisions during 2015-2016.

\begin{tabular}{|c|c|c|c|c|c|c|c|}
\hline \multicolumn{4}{|c|}{ Dera Ismael Khan } & \multicolumn{4}{|c|}{ Bannu } \\
\hline \multicolumn{2}{|c|}{ Parrot dealers } & \multicolumn{2}{|c|}{ Quail dealers } & \multicolumn{2}{|c|}{ Parrot dealers } & \multicolumn{2}{|c|}{ Quail dealers } \\
\hline Licensed & Unlicensed & Licensed & Unlicensed & Licensed & Unlicensed & Licensed & Unlicensed \\
\hline 2 & 8 & 14 & 6 & 0 & 6 & 0 & 12 \\
\hline
\end{tabular}

\section{Discussion}

Global bird trade network involves predominantly 18 countries including Indonesia that alone deals in some 157 bird species. Where songbirds trade consists of major $83.8 \%$ of total share and are listed among conservation concern species in the IUCN Red List. The most important bird's source was Lampung station while the West Java was important destination. About 1.04 million birds were exported from Southeast Asia, including 772,000 from captive-breeding facilities and 269,000 from the wild (Ferreira et al., 2009). International source of songbirds market works in Malaysia, from where they were smuggled to Indonesia. Another main destination for the smuggling of Parrots and Cockatoos is Philippines (Indraswari et al., 2020).

Bird trade is not new trade. It is prevalent since long time in the world. The people depend on the wild animals for subsistence. Hunting \& capture of birds for pet trade has reduced population size of several species (Alves, 2013). In Brazil birds are used for variety of purposes including medicine, food, pets and religious rituals. It was observed that since 1975, more than 3.3 million African parrots being traded, while there is no monitoring about this exploitation and there is no basic ecological data exist about the majority of species traded (Martin, 2018). Seemingly, the government does not have any proper documentation of the data related to general birds' trade in KPK province which can be used to analyze the impact of trade on natural resources.

Bird and human intimacy have long history in the Indian subcontinent. Birds were kept in royal courtyard. As for example, pigeons were used in wars as messengers while myna and parakeet as symbol of love and were favourite to Moghul emperors due to mimicking capability (Ahmed, 1997). However, in our study, in addition to keeping pets, the major use of wild bird is bush meat in case of common quail. This is in agreement with the results given by (Fernandes-Ferreira et al., 2012)

who found that tribes inhabiting Tensing district of Nagaland in India depend on wild animal for bush meat.

In Pakistan, wild birds are protected by law with the exception of Houbara which is mainly trapped and exported to Arab countries for falconry (Combreau, 2007). However, due to poverty driven forces, the poor and middle-class people get economic benefits by indulging into illegal trade of wild birds. This is in line with finding already reported (Mahmood et al., 2011). In 2006, trade of wild animal parts was reported with reference to turtles with the price of PkR 100-200 (Noureen et al., 2008).

Birds are released in many parts of the world particularly eastern and southern Asia as a symbol of peace and during celebration events (Gilbert et al., 2012). During the course of our study, it was observed that House sparrows are released on payment, as prayer bird by bird loving elite. In the present study, Bulbuls are traded traditionally only in Bannu where Marwat tribes have special affection for these birds and they tame them as partner during routine travel. This observation is in line with the results of Shepherd et al. (2013) where different species of bulbuls are preferred for their loud sounds in Singapore and Malaysia. Empress market of Karachi is best known for trade of various mammals and birds (da Nobrega et al., 2010)(Alves et al., 2010).

Our study further revealed that cranes are kept as pet birds and traded for various purposes including voice competitions which are held in Lakki Marwat, Saray Norang, Lundi Jalindhar and Bannu on regular basis. There were estimated 12000 captive cranes in Kurram valley of Pakhtunkhwa in Pakistan which were used for various purpose (Khan and Shahan, 1999). Approximately, 93\% cranes trapped in Bannu are used as pet, 5\% for dealing, $2 \%$ as meat in "sohbat/ local dish" (Tariq and Aziz, 2015).

During the course of our study, it was revealed that $75 \%$ species were traded illegally in Dera Ismael Khan and $100 \%$ species illegally traded in Bannu. Similar trend of illegal trade of birds was observed in markets of Multan and Rawalpindi markets. Wherein, Chukar partridges in Multan market were smuggled from Lakki Marwat (the part of present study) in air conditioned Buses \& coaches (Mahmood et al., 2011). The largest species of bird traded in Multan and Rawalpindi markets was of common quail and same is the result in our study. Quails are highly preferred bird species in our study area, which is in line with another study which revealed that estimated 38000 common quails were shot in just two months in 2004 in Serbia which indicates the diversity of species in wild (Simic and Tucakov, 2005). Alves et al. (2013) observed that about 295 bird species (23\% avifauna of country) are illegally sold as pets in Brazil which also conform to our study.

The price tag of birds depends upon how much distantly trafficked, importance of species, size, tameness and maintenance (Nascimento et al., 2015). During the study, it was found that the larger sized species of birds, Demoiselle crane, had greater prices with respect to smaller species i.e., House sparrow.

Markets called "Mela/Mandi" are organized weekly for local villagers for groceries and general shopping throughout Khyber Pakhtunkhwa which are the hot spots for commercial birds trade. There were more venders of birds trade in Bannu as compared to Dera Ismael Khan. Therefore, income generated by bird trade was five times greater in Bannu. The main reason behind it is fearless dealing of birds in Bannu 


\section{Conclusion}

The current study highlights the main birds species traded in southern parts Khyber Pakhtunkhwa and also indicates the amount of income generated. The main outcome of the study is the largely illegal status of trade. The species for which live trapping and dealing is banned are openly being sold mostly in Bannu division. Wildlife officials mainly pay their attention to the endangered species like Sakar and Peregrine falcons while ignoring other species of birds. It was noted during the study that a dealer having dealing license of one species is dealing many species of birds. There is dire need for policy makers to monitor these weekly markets for all species being sold.

\section{Acknowledgements}

Author is thankful to Higher Education Commission Islamabad for financial support for $\mathrm{PhD}$ program and also to administration of wildlife Dept. of KPK for providing valuable information regarding licensing record and data collection.

\section{References}

AHMED, A., 1997. Live bird trade in northern India.New Delhi: WWF/ TRAFFIC.

ALBUQUERQUE, U.P., RAMOS, M.A., DE LUCENA, R.F.P. and ALENCAR, N.L., 2014. Methods and techniques used to collect ethnobiological data. In: U.P.ALBUQUERQUE, L.V.F.C.CUNHA, R.F.P.LUCENA and R.R.N.ALVES, eds. Methods and techniques in ethnobiology and ethnoecology. New York: Springer, pp. 15-37. http://dx.doi.org/10.1007/978-1-4614-8636-7_2.

ALVES, R.R.N., 2012. Relationships between fauna and people and the role of ethnozoology in animal conservation. Ethnobiologyand Conservation, vol. 1, pp. 1-69. http://dx.doi.org/10.15451/ ec2012-8-1.2-1-69.

ALVES, R.R.N., LIMA, J.R.F. and ARAUJO, H.F.P., 2013. The live bird trade in Brazil and its conservation implications: an overview. Bird Conservation International, vol. 23, no. 1, pp. 53-65. http:// dx.doi.org/10.1017/S095927091200010X.

ALVES, R.R.N., NOGUEIRA, E.E.G., ARAUJO, H.F.P. and BROOKS, S.E., 2010. Bird-keeping in the Caatinga, NE Brazil. Human Ecology, vol. 38, no. 1, pp. 147-156. http://dx.doi.org/10.1007/ s10745-009-9295-5

COMBREAU, O., 2007. Arabic Falconry and the Illegal Houbara Trade in Arabia. Falco, 16-17.

DOUGHTY, R.W., 1975. Feather fashions and bird preservation: a study in nature protection. Berkeley: University of California Press, $183 \mathrm{p}$.

FERNANDES-FERREIRA, H., MENDONÇA, S.V., ALBANO, C., FERREIRA, F.S. and ALVES, R.R.N., 2012. Hunting, use and conservation of birds in Northeast Brazil. Biodiversity and Conservation, vol. 21, no. 1, pp. 221-244. http://dx.doi.org/10.1007/s10531-011-0179-9.

FERREIRA, F.S., BRITO, S.V., RIBEIRO, S.C., ALMEIDA, W.O. and ALVES, R.R., 2009. Zootherapeutics utilized by residents of the community PocoDantas, Crato-CE, Brazil. Journal of Ethnobiology and Ethnomedicine, vol. 5, no. 1, pp. 21. http:// dx.doi.org/10.1186/1746-4269-5-21. PMid:19656376.

GILBERT, M., SOKHA, C., JOYNER, P.H., THOMSON, R.L. and POOLE, C., 2012. Characterizing the trade of wild birds for merit release in Phnom Penh, Cambodia and associated risks to health and ecology. Biological Conservation, vol. 153, pp. 10-16. http:// dx.doi.org/10.1016/j.biocon.2012.04.024.

INDRASWARI, K., FRIEDMAN, R.S., NOSKE, R., SHEPHERD, C.R., BIGGS, D., SUSILAWATI, C. and WILSON, C., 2020. It's in the news: characterising Indonesia's wild bird trade network from media-reported seizure incidents. Biological Conservation, vol. 243, pp. 108431. http://dx.doi.org/10.1016/j.biocon.2020.108431.

INTERNATIONAL UNION FOR CONSERVATION OF NATURE - IUCN, 2014 [viewed 24 January 2021]. IUCN Red list [online]. Gland. Available from: https://www.iucnredlist.org

KHAN, A.S. and SHAHAN, N.1999 [viewed 24 January 2021]. Crane conservation in Pakistan [online]. Available from: www. pakistan.spp.com

LICARIÃO, M.R., BEZERRA, D.M. and ALVES, R., 2013. Wild birds as pets in Campina Grande, Paraíba State, Brazil: an ethnozoological approach. Anais da Academia Brasileira de Ciências, vol. 85, no. 1, pp. 201-213. http://dx.doi.org/10.1590/ S0001-37652013000100011.PMid:23538958.

MAHMOOD, T., SHAH, S.M.A., RAIS, M. and NADEEM, M.S., 2011. An investigation of animal species trade at pet shops of Rawalpindi and Multan cities. The Journal of Animal and Plant Science, vol. 21, no. 4, pp. 822-929.

MARTIN, R.O., 2018. The wild bird trade and African parrots: past, present and future challenges. The Ostrich, vol. 89, no. 2, pp. 139-143. http://dx.doi.org/10.2989/00306525.2017.1397787.

MIAN, A., 1986. Ecological impact of Arab falconry on Houbara Bustard in Balochistan. Environmental Conservation, vol. 13, no. 1, pp. 41-46. http://dx.doi.org/10.1017/S0376892900035852.

MIRZA, Z.B., 1985. Houbara in Cholistan. In: Proceedings of the International Symposium on Bustards, 1985, Peshawar. Cambridge: ICBP.

MIRZA, Z.B., 2007. A field guide to birds of Pakistan. Lahore: Bookland.

NADEEM, M.S., MIAN, A.A., ASIF, M., RASHID, H., AKHTAR, M.S. and MUJTABA, G., 2005. Houbara bustard: an experience of rearing chicks in Nag Valley (Balochistan), Pakistan. Berkut, vol. 142, pp. 246-254.

NASCIMENTO, C.A.R., CZABAN, R.E. and ALVES, R.R.N., 2015. Trends in illegal trade of wild birds in Amazonas state, Brazil. Tropical Conservation Science, vol. 8, no. 4, pp. 1098-1113. http://dx.doi. org/10.1177/194008291500800416.

NIJMAN, V., 2010. An overview of international wildlife trade from Southeast Asia. Biodiversity and Conservation, vol. 19, no. 4, pp. 1101-1114. http://dx.doi.org/10.1007/s10531-009-9758-4.

NOUREEN, U., BRAULIK, T.G., ARSHAD, M. and KHAN, H.N., 2008. Illegal trade in freshwater turtle parts: preliminary findings of turtle trade in major barrages and head-works of Punjab: report. Pakistan: Ministry of Environment's Pakistan Wetlands Programme, $28 \mathrm{p}$.

OLIVEIRA, W.S.L., BORGES, A.K.M., LOPES, S.F., VASCONCELLOS, A. and ALVES, R.R.N., 2020. Illegal trade of songbirds: an analysis of the activity in an area of northeast Brazil. Journal of Ethnobiology and Ethnomedicine, vol. 16, no. 1, pp. 16. http:// dx.doi.org/10.1186/s13002-020-00365-5.PMid:32228669.

OLIVEIRA, W.S.L., LOPES, S.F. and ALVES, R.R.N., 2018. Understanding the motivations for keeping wild birds in the semi-arid region of Brazil. Journal of Ethnobiology and Ethnomedicine, vol. 14, no. 1, pp. 1-14. http://dx.doi.org/10.1186/s13002-018-0243-6. PMid:29891010.

ROLDÁN-CLARÀ, B., LÓPEZ-MEDELLÍN, X., LEYVA, C., CALDERÓN DE LA BARCA, N. and ESPEJEL, I., 2017. Mexican birds use according to environmental officers. Ethnobiology and Conservation, vol. 6. http://dx.doi.org/10.15451/ec2017-08-6.13-1-18. 
SHAH, S.A., 2011. Conservation of endangered species in Khyber Pakhtunkhwa. Journal of Animal and Plant Sciences, vol. 21, no. 2, pp. 400-404.

SHEPHERD, C.R., 2006. The bird trade in Medan, North Sumatra: an overview. BirdingASIA, vol. 5, pp. 16-24.

SHEPHERD, C.R., SHEPHERD, L.A. and FOLEY, K.E., 2013. Straw-headed Bulbul Pycnonotuszeylanicus: legal protection and enforcement action in Malaysia. BirdingASIA, vol. 19, no., 1, pp. 92-94.
SIMIC, D. and TUCAKOV, M., 2005. Pobijeno 38000 prepelica. Dvogled, vol. 5-6, pp. 6.

TARIQ M. and AZIZ, R., 2015. Threats and hunting methods of crane species in District Karak of Khyber Pakhtunkhwa, Pakistan. Journal of Environment and Earth Science, vol. 5, no. 22, pp. 11-15.

TOLBORT, T., 1871. The district of Dera Ismail Khan, Trans-Indus. Whitefish, MT: Kessinger Publishing. 